\title{
Potential drug interactions and inappropriate medications prescribed for primary health care users
}

\author{
Rafaela Silva ROCHA ${ }^{1}$ (D), Luanna Gabriella da SILVA ${ }^{1}$ (D), Máyra Rodrigues FERNANDES ${ }^{1}$ (D), Roberta Carvalho de FIGUEIREDO ${ }^{1}$ (D), \\ André Oliveira BALDONI ${ }^{1}$ iD
}

${ }^{1}$ Universidade Federal de São João del-Rei, Divinópolis, MG, Brasil.

Correspondng author: Baldoni AO, andrebaldoni@ufsj.edu.br

Submitted: 17-04-2019 Resubmitted: 17-01-2020 Accepted: 08-05-2020

Peer review: blind reviewers

\begin{abstract}
Objectives: To analyze potential pharmacological interactions and drugs potentially inappropriate for the elderly in users of primary care of the Unified Health System. Methods: This is a cross-sectional study with individuals aged 18 years or over, who were approached at the health facilities of the city of Divinópolis, MG, at which time a home visit was scheduled. A structured questionnaire on drug use was applied and drug interactions were analyzed in Drugs.com ${ }^{\circledR}$ sources, Micromedex ${ }^{\circledR}$, bulletin of the Brazilian Health Regulatory Agency (ANVISA). Only the frequencies of serious interactions were analyzed. Potentially inappropriate drugs for elderly people (MPI) were identified by the Beers Criterion (2015) and the Brazilian Consensus on Potentially Inappropriate Medications for the Elderly (2016). The Mann-Whitney test was performed to compare the medians of the analyzed variables. Results: Among the study participants, $55 \%$ were elderly. Comparing them with the adult population, it was observed that the number of medications and potential drug interactions were significantly higher $(p<0.05$ ) among patients 60 years of age or older. Considering only the elderly, $77.3 \%$ used at least one MPI, according to the Beers Criterion. Conclusion: It was found that the vast majority of primary care users use at least one inappropriate drug and, when compared to adults, are more exposed to polypharmacy and potential drug interactions.
\end{abstract}

Keywords: drug interactions, pharmacoepidemiology, potentially inappropriate medication list, aged, primary health care.

\section{Potenciais interações medicamentosas e medicamentos inapropriados prescritos para usuários da atenção primária à saúde}

\section{Resumo}

Objetivo: Analisar as potenciais interações farmacológicas e os medicamentos potencialmente inapropriados para idosos em usuários da atenção primária do Sistema Único de Saúde. Métodos: Trata-se de um estudo transversal com indivíduos com idade igual ou superior a 18 anos, acompanhados em unidades de saúde do município de Divinópolis, Minas Gerais. Um questionário estruturado sobre uso de medicamentos foi aplicado durante visita domiciliar a uma amostra estratificada de usuários para investigação de interações medicamentosas potenciais e medicamentos potencialmente inapropriados para idosos (MPI), segundo Critério de Beers e Consenso Brasileiro de medicamentos potencialmente inapropriados para idosos. Foram utilizadas as fontes Drugs. com $^{\circledR}$, Micromedex ${ }^{\circledR}$ e bulário da Agência Nacional de Vigilância Sanitária (ANVISA) para análise das interações. Resultados: Dentre os participantes do estudo, 55\% eram idosos. Comparando-os com a população adulta, observou-se que o número de medicamentos e de potenciais interações medicamentosas foi significativamente superior $(p<0,05)$ entre pacientes com 60 anos ou mais. Considerando-se apenas os idosos, 77,3\% utilizavam ao menos um MPI. Conclusão: A maioria dos idosos da atenção primária no município de Divinópolis faz uso de ao menos um medicamento inapropriado, e, quando comparados aos adultos, estão mais expostos a polifarmácia e potenciais interações medicamentosas.

Palavras-chave: interações medicamentosas, farmacoepidemiologia, lista de medicamentos potencialmente inapropriados, idoso, atenção primária à saúde. 


\section{Introduction}

The use of drugs has become the most common form of therapy, which may be related to the increased availability and ease of access to drugs. But this use cannot always be associated with better health conditions or quality of life for the population ${ }^{1}$ Failures in prescription and dispensing, self-medication, and drug interactions can contribute to ineffective treatments, in addition to causing risks and harms to the health of the users².

The increasing trend in the use of drugs by the population favors the occurrence of drug interactions and serious adverse events ${ }^{3}$. A research study conducted by Obreli-Neto and collaborators ${ }^{3}$, during 2010 and 2011, showed that 37.0\% of the adverse drug reactions related to drug interactions culminated in hospitalization of older adults, all of which could have been avoided. In addition, potential drug interactions have been shown to be associated with the presence of polypharmacy ${ }^{3}$.

According to the study by Dumbreck and collaborators ${ }^{4}$, it is estimated that $6.5 \%$ of the unplanned hospitalizations in the UK are due to adverse drug events, and a proportion is caused by drug interactions.

Another factor that contributes to obtaining unwanted health results is the use of Potentially Inappropriate drugs (PIMs) for older adults. These drugs are those whose possible benefits are fewer than their potential risks, coupled with the existence of a therapeutic alternative with greater safety ${ }^{5}$. According to a study by Baldoni and collaborators ${ }^{6}$, the main factors associated with the use of PIMs are self-medication, the use of non-prescription drugs, psychotropic drugs, and polypharmacy. Silva and collaborators also demonstrated this relation between polypharmacy and PIMs, by showing that approximately $90.0 \%$ of the older adults were submitted to polypharmacy and that $59.0 \%$ had at least one prescription of a PIM. The results of Nascimento and collaborators ${ }^{8}$ associate the use of PIMs with mortality, pointing out that $56.0 \%$ of the older adults used PIMs and that the risk of death among PIM users was $44.0 \%$ higher than among those who did not use them.

In view of the above regarding the current medicalization scenario, the population aging process, and the scarcity of studies that explore in a comparative way the use of drugs in adults and older adults who are users of primary health care (PHC), the aim of the present study is to analyze the potential serious drug interactions and PIMs for the older adults prescribed to users of Primary health care of the Public Health System (Sistema Único de Saúde, SUS) in the municipality of Divinópolis, Minas Gerais.

\section{Methods}

\section{Study locus and population}

A cross-sectional study developed with users aged 18 years old or over, cared for in primary care units in the municipality of Divinópolis, in Minas Gerais. During the study period (September/2014-December/2016), the population was estimated at 230,848 thousand inhabitants ${ }^{9}$ and the municipality had 12 health regions, with fourteen Conventional Health Centers (CHCs), 20 units of the Family Health Strategy (FHS), and five public pharmacies for dispensing the basic component of Pharmaceutical Service.
To guarantee sampling diversity, the units were drawn from each of the health regions of the municipality. The number of units drawn was proportional to the number of units in each of the health regions. Regions with only one health unit were included in the sample. Thus, the strategy to recruit the participants consisted in the following steps: a) selecting, by draw, the health units in the municipality of Divinópolis; b) inviting users of the units, at random, while they were waiting to be cared for, until the sample targets were reached.

For the purpose of sample calculation, the following parameters were considered: a) prevalence, a priori, of $50 \%$, due to the variety of outcome variables; b) 5\% accuracy; c) $95 \%$ confidence level, and d) $10 \%$ losses, totaling 423 individuals to be interviewed. The total number of interviews in each health unit was defined proportionally to the number of patients seen in the respective units, using the simple rule of three for this.

\section{Selection of the participants and data collection}

The individuals were invited to participate in the study when they were in their health units receiving care. Trained interviewers explained the objectives of the study and extended the invitation. Upon acceptance of the patient, a home visit was scheduled. Before the visit, the Free and Informed Consent Form (FICF) was read and signed by the researcher and the interviewed, in two copies. Patients who used only one medication or who withdrew from the study were excluded from the study.

\section{Data collection instrument}

Before applying the data collection instrument, it was analyzed by three judges (researchers in the field of pharmacoepidemiology), for possible changes and adjustments. After this phase, the instrument was tested in a pilot study with 10 users of the SUS, to analyze their understanding of the questions. The complete questionnaire addressed questions about the drugs in use by the patient at the time of the interview, storage location, expiration dates for the drugs, and adherence to the pharmacological treatment.

\section{Potential drug interactions}

The potential drug interactions were first identified with the aid of Drugs.com ${ }^{\circledR 10}$ and, when the medication was not present in this database, the search was carried out in Micromedex ${ }^{\circledR 11}$, and in the electronic form of the ANVISA ${ }^{12}$, if necessary. Prior to the analysis, the drug interactions were classified by severity, according to Drugs.com ${ }^{\circledR 10}$ or to Micromedex ${ }^{\circledR 11}$ in the following categories: Minor: when the clinical risk was considered low, it is recommended to assess the risk, consider a therapeutic alternative, and insert a monitoring plan; Moderate: when the clinical risk was considered moderate, it is indicated to avoid the combination, using it only in special circumstances; Major: when the clinical risk was considered high, it is indicated to avoid the combination, as the risk exceeds the benefit ${ }^{10}$.

The clinical impact and management of potential serious interactions have been proposed based on data from Drugs. $\mathrm{com}^{\circledR 10}$ or Micromedex ${ }^{\circledR 11}$. For frequency analysis, only major interactions were considered, due to their clinical significance.

It should be noted that dipyrone was considered as a centrally acting analgesic, and not as a Non-Steroidal Anti-Inflammatory Drug (NSAID), as classified by Micromedex ${ }^{\circledR 11}$. 


\section{Drugs considered inappropriate for the older adults}

For respondents aged 60 or over, the adequacy of the use of drugs was analyzed. The drugs were categorized as adequate and inadequate, according to the Brazilian Consensus on inappropriate drugs for the older adults (2016) ${ }^{13}$ and to the Beers Criteria $(2015)^{5}$. Regarding the Beers Criteria, Tables 2 ( PIMs for use in older adults), 4 ( PIMs that should be used with caution in older adults), and 7 ( PIMs with deep anticholinergic properties) were considered. It were not considered: Tables 3 (due to lack of diagnosis), 5 (the drug interactions were analyzed using the sources already described), and 6 (due to lack of access to the patient's creatinine tests). The clinical impact and management of the use of drugs considered inappropriate for older adults were proposed based on the Beers Criteria $(2015)^{5}$ and in the narrative review carried out by Faria and collaborators ${ }^{14}$.

\section{Statistical analysis}

Data was entered into Epi Info version 7.0 and analyzed using the Statistical Package for the Social Sciences (SPSS). The normality of the data was analyzed by the histogram, kurtosis value, and asymmetry value. Variables with non-normal distribution were considered if the histogram was non-asymmetric and if kurtosis $>2$ or asymmetry $>7$. For comparison between the medians of the adults and the older adults, the Mann-Whitney test was used, as these are two groups of unpaired samples with non-normal distribution. After the analysis, it was observed that the variables did not present a normal distribution and, therefore, the data were presented in median and interquartile range (P25 - P75).

\section{Ethical aspects}

This study was approved by the Research Ethics Committee of the Federal University of São João del-Rei (Universidade Federal de São João del-Rei, UFSJ) - Dona Lindu Midwest Campus (Campus Centro Oeste, CCO). Approval protocol: CAAE 30912314.0.0000.5545.

\section{Results}

During the recruitment period, 612 medication users were invited to participate in the research. Of these, 163 refused to participate, 26 withdrew from the study and 70 used only one medication. Thus, 353 individuals were included in the study, of which 55\% ( $n=194)$ were older adults and 45\% ( $n=159)$, adults. The number of drugs used by the participants ranged from 2 to 25 . The medians of the number of drugs used by adults and older adults were $4(3-6)$ and $5(3-7)$, respectively, $(p<0.05)$.

The total amount of potential drug interactions (mild, moderate, and severe) varied from 0 to 48 per individual, and they were significantly more frequent in the older adults, when compared to the adults $(p<0.05)$. Considering only the 87 potential serious drug interactions found in both population groups, it was observed that the most frequent were between spironolactone and losartan, and between amlodipine and simvastatin (Table 1).

According to the Beers Criteria $(2015)^{5}, 55$ different drugs were identified as inappropriate (MPIs) or unsafe to be used in geriatrics. Whereas, considering the Brazilian Consensus of drugs potentially inappropriate for the older adults $(2016)^{13}$, that number dropped to 45 different types. The number of PIMs (Table 2) per individual varied from 0 to 7 , according to the Beers Criteria $(2015)^{5}$, and from 0 to 6 , according to the Brazilian Consensus of Inappropriate drugs for Older Adults (2016) ${ }^{13}$. Altogether, these drugs appeared 322 times, according to the Beers Criteria (2015) ${ }^{5}$ and 222 times, according to the Brazilian Consensus $(2016)^{13}$, among the participating older adults. The proportion of older adult patients who used at least one PIM was 77.3\%, according to the Beers Criteria $(2015)^{5}$ and, according to the Brazilian Consensus (2016)13, that figure dropped to $61.9 \%$.

Table 1. Major serious interactions in adults and older adults who are users of primary care in Divinópolis-MG, 2014-2016 ( $n=353$ ).

\begin{tabular}{|c|c|c|c|}
\hline Drug combination & Effect & Clinical management & Frequency \% (n) \\
\hline Spironolactone and losartan & Risk of hyperkalemia & Monitor potassium levels and renal function & $2.8(10)$ \\
\hline Amlodipine and simvastatin & $\begin{array}{l}\text { Increases plasma concentrations of simvastatin, } \\
\text { potentiating the risk of myopathy }\end{array}$ & $\begin{array}{l}\text { Do not exceed } 20 \mathrm{mg} / \text { day simvastatin } \\
\text { or replace therapy with rosuvastatin, } \\
\text { pravastatin, and fluvastatin }\end{array}$ & $2.6(8)$ \\
\hline ASA and ketorolac & Potentiates adverse effects of NSAIDs & Avoid simultaneous use & $0.6(2)$ \\
\hline ASA and nimesulide & Increases the risk of bleeding & $\begin{array}{l}\text { Monitor for signs of bleeding. Take ASA two } \\
\text { hours before the NSAID }\end{array}$ & $0.6(2)$ \\
\hline $\begin{array}{l}\text { Amitriptyline and } \\
\text { cyclobenzaprine }\end{array}$ & Increases serotonin levels & $\begin{array}{l}\text { Avoid concomitant use. Monitor serotonin } \\
\text { syndrome symptoms }\end{array}$ & $0.6(2)$ \\
\hline Amitriptyline and sertraline & Increases serotonin levels & $\begin{array}{l}\text { Monitor signs and symptoms of serotonin } \\
\text { syndrome and avoid association }\end{array}$ & $0.6(2)$ \\
\hline Betamethasone and nimesulide & $\begin{array}{l}\text { Increases the risk of gastrointestinal ulcers and } \\
\text { bleeding }\end{array}$ & $\begin{array}{l}\text { Monitor signs and symptoms when } \\
\text { association is needed }\end{array}$ & $0.6(2)$ \\
\hline Captopril and spironolactone & Risk of hyperkalemia & Monitor potassium levels & $0.6(2)$ \\
\hline Cyclobenzaprine and sertraline & Risk of serotonin syndrome & Monitor symptoms of serotonin syndrome & $0.6(2)$ \\
\hline Clopidogrel and omeprazole & Inhibition of the effects of clopidogrel & $\begin{array}{l}\text { Avoid simultaneous use. Choose } \\
\text { pantoprazole/lansoprazole instead }\end{array}$ & $0.6(2)$ \\
\hline Colchicine and simvastatin & Risk of myopathy & $\begin{array}{l}\text { Monitor creatine kinase levels, although this } \\
\text { does not prevent the occurrence of myopathy }\end{array}$ & $0.6(2)$ \\
\hline Diclofenac and nimesulide & $\begin{array}{l}\text { Increases the risk of bleeding, renal, } \\
\text { cardiovascular and gastrointestinal impairment. }\end{array}$ & Avoid simultaneous use & $0.6(2)$ \\
\hline $\begin{array}{l}\text { Hydrochlorothiazide and } \\
\text { nimesulide }\end{array}$ & $\begin{array}{l}\text { Reduces diuretic effects and possible } \\
\text { nephrotoxicity }\end{array}$ & Monitor renal function & $0.6(2)$ \\
\hline Sertraline and tramadol & Risk of serotonin syndrome & Monitor symptoms of serotonin syndrome & $0.6(2)$ \\
\hline
\end{tabular}


Table 2. Potentially inappropriate drugs for older adults who are users of primary care of Divinópolis-MG, 2014-2016 ( $n=194$ )

\begin{tabular}{|c|c|c|c|c|c|}
\hline \multirow{2}{*}{$\begin{array}{l}\text { Medication } \\
\text { n (\%) }\end{array}$} & \multicolumn{2}{|c|}{$\begin{array}{l}\text { Brazilian Consensus on Potentially Inappropriate drugs for } \\
\text { the Older Adults, } 2016\end{array}$} & \multicolumn{3}{|c|}{ Beers Criteria, 2015} \\
\hline & Rational & Exception & Recommendation & $\begin{array}{l}\text { Degree of } \\
\text { recomm. }\end{array}$ & $\begin{array}{l}\text { Quality of the } \\
\text { evidence }\end{array}$ \\
\hline $\begin{array}{l}\text { Hydrochlorothiazide } \\
61(31.4)\end{array}$ & $\begin{array}{l}\text { Contraindication is dependent } \\
\text { on clinical condition (gout) }\end{array}$ & None & Use with caution & Strong & Moderate \\
\hline $\begin{array}{l}\text { Omeprazole } \\
42(21.6)\end{array}$ & $\begin{array}{l}\text { Prolonged use can contribute } \\
\text { to the development of } \\
\text { osteoporosis, fracture, } \\
\text { dementia, and renal failure }\end{array}$ & $\begin{array}{l}\text { Dose reduction in the } \\
\text { treatment of peptic } \\
\text { ulcer, esophagitis, and } \\
\text { gastroesophageal reflux } \\
\text { disease. Discontinuation } \\
\text { before eight weeks }\end{array}$ & $\begin{array}{l}\text { Avoid use for }>8 \text { weeks. } \\
\text { Except in the treatment of } \\
\text { erosive esophagitis, Barrett's } \\
\text { esophagitis, and pathological } \\
\text { hypersecretory condition }\end{array}$ & Strong & High \\
\hline $\begin{array}{l}\text { Clonazepam } \\
21(10.8)\end{array}$ & Can induce delirium & $\begin{array}{l}\text { Treatment of epileptic } \\
\text { seizures, REM sleep disorders, } \\
\text { benzodiazepine and ethanol } \\
\text { withdrawal syndrome, severe } \\
\text { generalized anxiety disorder, } \\
\text { in perioperative anesthesia } \\
\text { and palliative care }\end{array}$ & Avoid & Strong & Moderate \\
\hline $\begin{array}{l}\text { Furosemide } \\
17(8.8)\end{array}$ & $\begin{array}{l}\text { Safer and more effective } \\
\text { alternatives available }\end{array}$ & None & Use with caution & Strong & Moderate \\
\hline $\begin{array}{l}\text { Spironolactone } \\
14(7.2)\end{array}$ & $\begin{array}{l}\text { Risk of hyperkalemia in } \\
\text { patients with heart failure }\end{array}$ & None & Use with caution & Strong & Moderate \\
\hline $\begin{array}{l}\text { Diclofenac } \\
12(6.2)\end{array}$ & $\begin{array}{l}\text { May exacerbate the risk of } \\
\text { gastrointestinal bleeding and } \\
\text { peptic ulcer }\end{array}$ & $\begin{array}{l}\text { If there are no other } \\
\text { alternatives }\end{array}$ & Avoid chronic use & Strong & Moderate \\
\hline $\begin{array}{l}\text { Sertraline } \\
11(5.7)\end{array}$ & $\begin{array}{l}\text { Contraindication is dependent } \\
\text { on clinical condition (history } \\
\text { of falls/fractures and } \\
\text { hyponatremia) }\end{array}$ & None & Use with caution & Strong & Moderate \\
\hline $\begin{array}{l}\text { Glibenclamide } \\
10(5.2)\end{array}$ & $\begin{array}{l}\text { Risk of prolonged } \\
\text { hypoglycemia }\end{array}$ & None & Avoid & Strong & High \\
\hline $\begin{array}{l}\text { Chlorpheniramine } \\
9(4.6)\end{array}$ & Risk of anticholinergic effects & $\begin{array}{l}\text { In allergic reaction, use } \\
\text { diphenhydramine }\end{array}$ & Avoid & Strong & Moderate \\
\hline
\end{tabular}

Source: Beers Criteria $(2015)^{5}$, Brazilian Consensus on potentially inappropriate drugs for the older adults (2016) ${ }^{13}$

\section{Discussion}

The exponential increase in chronic diseases and factors associated with aging contributes significantly to the difference between the pharmacoepidemiological profile of the older adults and of the adults. The greatest number of drugs used by the older adults is associated with sociodemographic, clinical, and pharmacotherapeutic factors ${ }^{15}$.

Due to the high amount of drugs used by the population, impacts in the clinical and economic scope are generated, in addition to putting patient safety at risk, as this factor increases the chance of potential drug interactions ${ }^{16}$. The results obtained reinforce the need for greater attention when in a geriatric population, since there is a greater chance of occurrence of these interactions, which was evidenced by the medians of the number of drug interactions between adults and older adults: 1 (0-3) and 3 (1-5), respectively, with $\mathrm{p}<0.05$.

The significant discrepancy in the number of drug interactions between adults and older adults can be associated with the frequency of polypharmacy ${ }^{17}$. It can also be associated with some physiological conditions of aging, such as slower gastric emptying and reduced enzyme activity in the liver, which may also increase the impact of these drug interactions ${ }^{18}$.

The most prevalent serious interactions were between spironolactone and losartan and between amlodipine and simvastatin. The concomitant use of angiotensin II receptor blockers (losartan) and potassium-sparing diuretics (spironolactone) may increase the risk of hyperkalemia. This association can be fatal in patients with risk factors such as chronic kidney disease, diabetes, old age, and severe heart failure ${ }^{10}$. The administration of amlodipine can significantly increase plasma concentrations of simvastatin and its active metabolite, and also increase the risk of statin-induced myopathy ${ }^{10}$.

Given this, the prescription is of great importance for patient safety, because problems related to the use of drugs can be avoided at that moment. And on the other hand, it is important to note that inappropriate prescriptions can lead to the use of drugs that have a high risk of adverse events when there are equal or more effective alternatives with lower risks ${ }^{13}$.

As the older adults are more vulnerable to adverse situations resulting from the use of drugs, their prescriptions require strategies aimed at reducing the risk of clinical problems arising 
from drug interactions ${ }^{16}$. The use of potentially inappropriate drugs for the older adults can trigger adverse effects and problems, most of the time, avoidable. Therefore, the study and identification of the inappropriate therapy for this audience can be used to develop strategies to ensure patient safety ${ }^{7}$.

When compared to another two Brazilian studies, the prevalence of PIMs found in the present study was higher than that found by Silva and collaborators ${ }^{7}(59.0 \%)$, and lower than that found in the study by Ulbrich, Cusinato, and Guahyba ${ }^{19}$ (93.5\%). This high prevalence of the use of PIMs is a public health problem, since it can result in a greater risk of hospitalization and in factors which worsen the mortality rates ${ }^{8}$. Thus, the clinical conditions of the older adults, the drugs in use, lifestyle, and the scientific evidence should serve as a basis for assessing the clinical impact on the patient's life and providing guidance on the use of PIMs.

In relation to the limitations of the study, it is important to highlight that the research was carried out only with users of the Public Health System (Sistema Único de Saúde, SUS) of a Brazilian municipality, not allowing for the extrapolation of the results, although it is observed in the literature that the profile of medication use in primary health care is similar among the Brazilian municipalities, due to the fact that the Municipal Lists of Essential drugs (Relações Municipais de Medicamentos Essenciais, REMUME) are guided by protocols and clinical guidelines which are used throughout the national territory and by the National List of Essential drugs (Relação Nacional de Medicamentos Essenciais, RENAME). In addition, another possible limitation that needs to be highlighted is the potential selection bias that exists, since the invitation to include the participants in the research was extended according to the order of arrival and to the acceptance of the patients who were in the units awaiting care. This was done until the sample goals were reached in each health unit.

In order to reduce the gap between scientific research and the needs of the health services, the findings of the present study made it possible to prepare two pharmacotherapeutic bulletins, namely: "Pharmacotherapeutic bulletin 01/2017: Safety in the use of drugs by the older adults" 20 and "Pharmacotherapeutic Bulletin 02/2017: Drug interactions"21. As a return to the municipality, these bulletins were sent to the Municipal Health Secretariat of Divinópolis and posted in health units in order to alert the health team about the risks that the patients are exposed to.

Finally, it is important to highlight that it is extremely important for the health professionals to know these drug interactions and the profile of potentially dangerous drugs for the older adults, as well as their impact and clinical management in order to monitor their use, avoid them when possible, and act in a way to contribute to the rational use of drugs, providing an improvement in the effectiveness and safety in the use of drugs $^{3}$.

\section{Conclusion}

Most older adults who are primary care users use at least one medication that is inappropriate for them and, when compared to the adults, are more exposed to a high number of drugs and to potential drug interactions. Such an event may imply increased costs and overload for the health systems. Thus, the rationalization of the use of drugs is one of the significant public health challenges, since the presence of polypharmacy, the practice of self-medication, and potentially inappropriate prescriptions are still prevalent, especially among the older adults.

\section{Funding sources}

National Council for Scientific and Technological Development (CNPq). This study was financed in part by the Coordenação de Aperfeiçoamento de Pessoal de Nível Superior - Brasil (CAPES) . Finance Code 001.

\section{Collaborators}

RSR, MRF, RFC, and $A O B$ participated in the conception and design, and in data analysis and interpretation. RSR, LGRS and $A O B$ contributed to the writing of the article and with the relevant critical review of the intellectual content. RSR, LGRS, MRF, RFC, and $A O B$ approved the final version to be published and declare responsibility for all the information on the work, ensuring the accuracy and integrity of any its parts.

\section{Acknowledgments}

We thank the Federal University of São João Del-Rei (Universidade Federal de São João Del-Rei, UFSJ) for encouraging the research, and the Municipal Health Secretariat of Divinópolis (Secretaria Municipal de Saúde de Divinópolis, SEMUSA) for their support.

\section{Conflict of interest statement}

The authors declare that there are no conflicts of interest regarding this article.

\section{References}

1. Silva CDC. Por uma filosofia do medicamento. Cien Saude Colet. 2015;20(9).

2. Pereira JR, Soares $L$, Hoepfner $L$, et al. Riscos da automedicação: tratando o problema com conhecimento. Univille. 2006.

3. Obreli Neto PR, Nobili A, Lyra DP, et al. Incidence and predictors of adverse drug reactions caused by drug-drug interactions in elderly outpatients: A prospective cohort study. J Pharm Pharm Sci. 2012;15(2):332-43.

4. Dumbreck S, Flynn A, Nairn M, et al. Drug-disease and drugdrug interactions: systematic examination of recommendations in 12 UK national clinical guidelines. BMJ. 2015;350:1-8.

5. American Geriatrics Society. Beers Criteria Update Expert Panel. American Geriatrics Society 2015 Updated Beers Criteria for Potentially Inappropriate Medication Use in Older Adults. J Am Geriatr Soc. 2015;63(11):1-20.

6. Baldoni ADO, Ayres LR, Martinez EZ, et al. Factors associated with potentially inappropriate drugs use by the elderly according to Beers Criteria 2003 and 2012. Int J Clin Pharm. 2014;36(2):316-24.

7. Silva DCG, Pereira ML, Soares DB, et al. Potentially inappropriate medication use among elderly patients from a Brazilian general hospital. Infarma Ciências Farm. 2016;28:27-32.

8. Nascimento MMG, Mambrini JVM, Lima-Costa MF, et al. Potentially inappropriate drugs: predictor for mortality in a cohort of community-dwelling older adults. Eur J Clin Phar- 
macol. 2017;73(5):615-21.

9. DataSus [homepage na Internet]. Departamento de Informática do SUS. Avaliable in: http://datasus.saude.gov.br/. Accessed on Oct 23, 2018.

10. Drugs [Homepage na Internet] Interactions Checker. Available in:https://www.drugs.com/. Accessed on Oct 23, 2018.

11. Micromedex [Homepage na Internet].Avaliable in: https:// psbe.ufrn.br/index.php?option=com_content\&view=article\&id=36\&ltemid=248. Accessed on: 15 Apr 2017.

12. Bulário Eletrônico - ANVISA [Homepage na Internet] [acesso em 09 dez 2019]. Available in: http://www.anvisa.gov.br/datavisa/fila_bula/index.asp. Accessed on: 21 Abr 2017.

13. Oliveira MG, Amorim WW, Oliveira CRB, et al. Consenso brasileiro de medicamentos potencialmente inapropriados para idosos. Geriatr Gerontol Aging. 2016;10(4):168-81.

14. Faria Al, Obreli-neto PR, Guidoni CM, et al. Análise dos medicamentos potencialmente inapropriados para idosos contidos na Relação Municipal dos Medicamentos Essenciais (REMUME) de Divinópolis-MG. J Appl Pharm Sci. 2015;2(1):48-69.

15. Baldoni AO, Ayres LR, Martinez EZ, et al. Pharmacoepidemiological profile and polypharmacy indicators in elderly outpatients. Brazilian J Pharm Sci. 2013;49(3):443-52.

16. Linjakumpu T, Hartikainen S, Klaukka T, et al. Use of drugs and polypharmacy are increasing among the elderly. J Clin Epidemiol. 2002;55(8):809-17.

17. Leão DFL, Moura CS, Medeiros DS. Avaliação de interações medicamentosas potenciais em prescrições da atenção primária de Vitória da Conquista (BA), Brasil. Cien Saude Colet. 2014;19(1):511-8.

18. Lima TAM, Furini AAC, Atique TSC, et al. Análise de potenciais interações medicamentosas e reações adversas a anti-inflamatórios não esteroides em idosos. Revista Brasileira de Geriatria e Gerontologia. 2016;19(3):533-44.

19. Ulbrich AHDPS, Cusinato CT, Guahyba RS. Medicamentos potencialmente inapropriados (MPIS) para idosos : prevalência em um hospital terciário do Brasil. Rev Bras Farm Hosp Serv Saúde. 2017;8(3):14-8.

20. Boletim informativo da Liga Acadêmica de Farmácia Clínica. Segurança no uso de medicamentos. Available in: https:// ufsj.edu.br/lafarc/boletins_farmacoterapeuticos.php. Accessed on: 18 Dec 2019

21. Boletim informativo da Liga Acadêmica de Farmácia Clínica. Interações medicamentosas. Available in: https://ufsj.edu.br/ lafarc/boletins_farmacoterapeuticos.php. Accessed on: 18 Dec 2019. 